Atmos. Chem. Phys. Discuss., https://doi.org/10.5194/acp-2018-1249

Manuscript under review for journal Atmos. Chem. Phys.

Discussion started: 17 December 2018

(c) Author(s) 2018. CC BY 4.0 License.

\title{
RAMS-MLEF Atmosphere-Aerosol Coupled Data Assimilation: A Case Study of A Dust Event over the Arabian Peninsula on 4 August 2016
}

Ting-Chi $\mathrm{Wu}^{1}$, Milija Zupanski ${ }^{1}$, Stephen Saleeby ${ }^{2}$, Anton Kliewer ${ }^{1}$, Lewis Grasso ${ }^{1}$, Qijing Bian ${ }^{2}$, 5 Samuel A. Atwood ${ }^{2}$, Yi Wang ${ }^{3}$, and Jun Wang ${ }^{3}$

${ }^{1}$ Cooperative Institute for Research in the Atmosphere, Colorado State University, Fort Collins, CO, U.S.A.

${ }^{2}$ Department of Atmospheric Science, Colorado State University, Fort Collins, CO, U.S.A.

${ }^{3}$ Department of Chemical and Biochemical Engineering, Interdisciplinary Graduate Program in Informatics, and Center for Global and Regional Environmental Research, The University of Iowa, Iowa City, IA, U.S.A.

10

Correspondence to: Ting-Chi Wu (ting-chi.wu@colostate.edu)

Abstract. The Regional Atmospheric Modeling System (RAMS) has been interfaced with the Maximum Likelihood Ensemble Filter (MLEF) with the goal of improving initial conditions for aerosol weather forecasting via atmosphere-aerosol coupled data assimilation (RAMS-MLEF). In order to assimilate satellite retrieved aerosol optical depth (AOD), an AOD

15 observation operator customized for the RAMS aerosol module is implemented. Two MLEF-RAMS experiments are carried out for a dust storm event over the Arabian Peninsula that occurred on 4 August 2016. In the first experiment, conventional atmospheric observations from the National Centre for Environmental Prediction (NCEP) Prepared Binary Universal Form for the Representation of meteorological data (PrepBUFR) dataset are assimilated (ATMONLY), while both the atmospheric observations and AOD retrievals from Moderate Resolution Imaging Spectroradiometer (MODIS) are assimilated in the second experiment (ATMAOD). In the two experiments, a list of control variables is used and it includes the threedimensional wind components, perturbation Exner function, ice-liquid water potential temperature, total water mass mixing ratio, and the two dust modes from the aerosol module. Results indicate that the assimilation of MODIS AOD retrievals improves the representation of the dust plume over Persian Gulf, however, has no obvious impact on the dust plume interior of Saudi Arabia. Such finding is further supported by the examination of analysis increments of some control variables and the information measure in terms of degrees of freedom for signal. This is likely due to the lack of AOD retrievals interior of the Arabian Peninsula. Finally, a 12-h forecast initialized from both experiments is conducted. In general, ATMAOD forecast better represents the Persian Plume but performs poorly for the Saudi Plume, when verified against the aerosol reanalysis product from the Modern-Era Retrospective Analysis for Research and Applications version 2 (MERRA-2) dataset. 
Atmos. Chem. Phys. Discuss., https://doi.org/10.5194/acp-2018-1249

Manuscript under review for journal Atmos. Chem. Phys.

Discussion started: 17 December 2018

(c) Author(s) 2018. CC BY 4.0 License.

\section{Introduction}

There has been an increasing interest over the last two decades in assimilating aerosol and/or chemistry data into numerical models to improve the forecast of aerosol weather (Collins et al., 2001, Wang et al., 2003, Weaver et al., 2007, Wang and Niu, 2013, Zhang et al., 2014, Randles et al., 2017). On the modelling perspective, there are, in general, two approaches for

5 this type of study. One approach is to use an offline aerosol model that is driven by meteorological fields produced by an atmospheric model (e.g., Sekiyama et al., 2010, Rubin et al., 2017). For this type of approach, interactions between the atmospheric model and the aerosol model are one-way. That is, the meteorological fields from an atmospheric model are used to initialize the aerosol model, but the outcome from the aerosol model is not fed back to the atmospheric model. Another approach is to use an atmosphere-aerosol coupled modelling system (e.g., Liu et al., 2011, Lee et al., 2017), in

10 which a simultaneous forecast of both meteorological and aerosol fields are performed and the interactions between both atmospheric and aerosol components are two-way. One such example is the Weather Research and Forecasting model coupled with Chemistry (WRF-Chem) (Grell et al., 2005).

On the data assimilation perspective, depending on how the modelling components interact with each other, there exists

15 three general regimes for this type of study: i) an uncoupled, ii) a weakly coupled, and iii) a strongly coupled systems. As summarized in Županski (2017), an uncoupled data assimilation system simply means that each component is completely independent in both data assimilation and forecast aspects. A weakly coupled data assimilation system performs data assimilation separately for each component. The updated initial conditions for both meteorological and aerosol fields are then used to initialize a coupled forecast. Specifically, the cross-component elements in the forecast error covariance matrix

20 are not considered during data assimilation update. Finally, a strongly coupled data assimilation system conducts both data assimilation and forecast in a coupled sense. Since the cross-component elements in the forecast error covariance matrix are used in a coupled data assimilation system, observational information from one component has a potential to influence other components (Zupanski et al., 2018).

25 Similar to WRF-Chem, the Colorado State University (CSU) Regional Atmospheric Modeling System (RAMS) is also an atmosphere-aerosol coupled modelling system that is capable of simulating aerosol and cloud microphysical processes across multiple atmospheric scales. In this study, RAMS is interfaced with an ensemble-based data assimilation system, the Maximum Likelihood Ensemble Filter (MLEF), for the first time. Such atmosphere-aerosol coupled data assimilation system will be referred to as RAMS-MLEF hereafter. Following the above discussion, the RAMS-MLEF system is configured as a

30 strongly coupled system in the sense that a set of control variables is chosen to represent both the meteorological and aerosol fields. The goal of this study is to assimilate aerosol optical depth (AOD) retrievals in the RAMS-MLEF system to improve the representation and forecast of the spatial and temporal distribution of aerosol in the littoral zone. 
Atmos. Chem. Phys. Discuss., https://doi.org/10.5194/acp-2018-1249

Manuscript under review for journal Atmos. Chem. Phys.

Discussion started: 17 December 2018

(c) Author(s) 2018. CC BY 4.0 License.

(c) (i)

AOD retrievals derived from the Moderate Resolution Imaging Spectroradiometer (MODIS) provide a near global coverage of aerosol distribution (Remer et al., 2013). Specifically, the Deep Blue (DB) algorithm over land (Hsu et al., 2006) along with those derived by Dark Target (DT) algorithm over land (DT-land) and over ocean (DT-ocean) (Levy et al., 2013) are three major MODIS AOD retrievals that have been widely used in the research community. Nevertheless, retrievals of AOD

5 over turbid costal water has been challenging due to large variability in the ocean color along the costal regions. Wang et al., (2017) developed an algorithm that takes the advantage of negligible radiances at $2.1 \mu \mathrm{m}$ regardless of water turbidity and assumes that the aerosol single scattering properties over turbid water are similar to those over adjacent open ocean scenes. Their technique is referred to as Costal Water (CW) algorithm. As a consequence, the $\mathrm{CW}$ algorithm not only complements the existing DT-ocean algorithm by filling the observational gap in costal regions, but also improves MODIS AOD retrieval

10 evaluation against collocated Aerosol Robotic Network (AERONET) sites (Wang et al., 2017). In this study, 3-km DT-land and DT-ocean AOD retrievals at $550 \mathrm{~nm}$ (or $0.55 \mu \mathrm{m}$ ) along with 3-km CW AOD retrievals at the same wavelength are used for data assimilation and are hereafter referred to as MODIS AOD retrievals.

The rest of the manuscript is organized as follows: section 2 describes the development of interfaces to connect RAMS with

15 MLEF for a atmosphere-aerosol coupled data assimilation system along with an implementation of an AOD observation operator for RAMS, section 3 provides the case study and section 4 describes the experimental design followed by results presented in section 5. Finally, section 6 includes a summary and conclusions.

\section{Interfacing RAMS with MLEF}

\subsection{RAMS model}

20 RAMS is a multi-purpose mesoscale numerical prediction model that was developed at CSU (Cotton et al., 2003). Throughout the years, RAMS has undergone multiple upgrades that include improvements to its microphysics via the implementation of a cloud nucleation scheme (Saleeby and Cotton, 2004), an improved capability to assimilate lightning data (Federico et al., 2017), an implementation of a non-local boundary layer scheme (Gómez et al., 2016), and the development of an aerosol module (Saleeby and Van den Heever, 2013). Out of these recent upgrades, the development of a RAMS aerosol module is directly related to the study herein.

There are a total of nine aerosol species represented by the aerosol module in RAMS: i) submicronmeter sulphate, ii) supermicrometer sulphate, iii) submicrometer mineral dust, iv) supermicrometer mineral dust, v) film-mode sea salt, vi) jet drop-mode sea salt, vii) spume-mode sea salt, viii) submicrometer regenerated aerosols, and ix) supermicrometer regenerated aerosols. For each aerosol type, the size is represented by a lognormal distribution given by 
Atmos. Chem. Phys. Discuss., https://doi.org/10.5194/acp-2018-1249

Manuscript under review for journal Atmos. Chem. Phys.

Discussion started: 17 December 2018

(c) Author(s) 2018. CC BY 4.0 License.

(c) (i)

Atmospheric

Chemistry

and Physics

Discussions

$n(r)=\frac{N}{r \sqrt{2 \pi} \ln \sigma_{g}} \exp \left[-\frac{\left(\ln \frac{r}{r_{g}}\right)^{2}}{2 \ln ^{2} \sigma_{g}}\right]$

where $n(r)$ is number concentration of aerosols of dry radius $r, N$ is total number concentration of aerosols, $r_{g}$ is lognormal distribution geometric median radius, and $\sigma_{g}$ is lognormal distribution geometric standard deviation. Although the shape of the size distribution as described in (1) is fixed during a simulation, the shape is allowed to translate in the direction of $r$.

5 That is, as a result of sources and sinks of aerosol mass during a simulation, the shape of (1) is allowed to shift toward larger or smaller values of $r$. In addition, the width of the size distribution is determined by $\sigma_{g}$, which behaves like a dispersion parameter in a Gamma size distribution used in microphysical development.

\subsection{MLEF}

MLEF is an ensemble data assimilation algorithm based on control theory developed by Zupanski (2005) and Zupanski et al.

10 (2008). In other words, MLEF is a hybrid data assimilation algorithm with both variational and ensemble features. As illustrated by Fig. 1, during the forecast step, MLEF generates an ensemble of forecasts to estimate the flow-dependent forecast error covariance, while during the analysis step, the nonlinearity of observation operators are considered by utilizing an iterative minimization of a cost function described by

$J(\mathbf{x})=\frac{1}{2}\left(\mathbf{x}-\mathbf{x}_{\mathbf{f}}\right)^{T} \mathbf{P}_{\mathbf{f}}^{-1}\left(\mathbf{x}-\mathbf{x}_{\mathbf{f}}\right)+\frac{1}{2}[\boldsymbol{y}-h(\mathbf{x})]^{T} \mathbf{R}^{-1}[\boldsymbol{y}-h(\mathbf{x})]$

15 where $\mathbf{x}$ and $\mathbf{y}$ define state vector and the observation vector respectively. The subscript $\mathbf{f}$ denotes the forecast and superscript $\mathrm{T}$ and -1 are used to denote the transpose and inverse of a matrix respectively. $\mathbf{P}_{\mathbf{f}}$ is the forecast error covariance and $\mathbf{R}$ is the observation error covariance, which is often a diagonal matrix following the assumption that observations are not spatially correlated. $h$ denotes a collection of nonlinear observation operators.

20 A large part of this study focused on developing interfaces to connect RAMS with MLEF, hence, the RAMS-MLEF system. This system is different from the CSU Regional Atmospheric Modeling Data Assimilation System (RAMDAS, Zupanski et al., 2005). To address the developmental work, a schematic diagram as shown in Fig. 1 outlines the RAMS-MLEF system. Specifically, three major interfaces are implemented in MLEF and they are 1) I/O interfaces between MLEF and RAMS, 2) an interface that acts as a driver to call and run RAMS, and 3) an interface for observation operators that utilize input from

25 RAMS for assimilation. In MLEF, observation operators for conventional atmospheric observations are adapted from the forward component of the Gridpoint Statistical Interpolation (GSI, Wu et al., 2002, Kleist et al., 2009) through a module (ATM in the orange box of Fig. 1). With that, atmospheric observations that are provided by the National Centre for Environmental Prediction (NCEP), such as the conventional observations within the NCEP Prepared Binary Universal Form for the Representation of meteorological data (PrepBUFR) dataset and satellite radiances data from various platforms, can be 
Atmos. Chem. Phys. Discuss., https://doi.org/10.5194/acp-2018-1249

Manuscript under review for journal Atmos. Chem. Phys.

Discussion started: 17 December 2018

(c) Author(s) 2018. CC BY 4.0 License.

(c) (i)

assimilated by MLEF in parallel/conjunction with operational approach. However, the AOD observation operator that is embedded in the Community Radiatve Transfer Model (CRTM, Han et al., 2006), which is part of the forward operators of GSI, was built for the Goddard Chemistry Aerosol Radiation and Transport (GOCART, Chin et al., 2000) aerosol species. Therefore, there is a need to develop an AOD operator specifically for RAMS aerosol module in MLEF.

\section{$5 \quad 2.3$ AOD Observation Operator for RAMS}

Following Liu et al., (2011) and Pagowski et al., (2014), an observation operator for AOD at a given wavelength $\lambda(\mathrm{nm})$, is calculated by the following equation

$$
A O D(\lambda)=\mathrm{const} \cdot \sum_{i=1}^{N_{\text {aero }}} \sum_{k=1}^{k_{\text {top }}} E_{\text {ext }}\left(\lambda, n_{r i}, r_{\text {effi }}\right) \cdot c_{i k} \cdot \frac{\Delta p_{k}}{g}
$$

where $A O D(\lambda)$ represents the spectrally dependent AOD operator (unit less), $i$ is the index for aerosol species, $N_{\text {aero }}$ is the

10 total number of aerosol species that contribute to the AOD calculation, $k$ is the index for model vertical levels, and $k_{t o p}$ is the model top level. $E_{\text {ext }}$ is the spectrally dependent mass extinction coefficient $\left(\mathrm{m}^{2} \mathrm{~g}^{-1}\right)$, which is a function of the index of refraction $n_{r}$ and effective radius $r_{\text {eff }}(\mathrm{nm})$ of a given aerosol species, $c_{i}$, in the form of mass mixing ratio $(\mathrm{g}$ of species $/ \mathrm{kg}$ of dry air). $\Delta p_{k}$ is pressure difference ( $\mathrm{mb}$ ) between two vertical levels $k$ and $k+1$, and $g$ is the acceleration due to gravity ( $\mathrm{m} \mathrm{s}^{-}$ ${ }^{2}$ ). const is a constant of $10^{5}$, as a result of unit conversion.

15

Out of the nine aerosol species, six of them are used in (3), i.e., $N_{\text {aero }}=6$, to calculate AOD for this study. Supermicrometer sulphate is not used due to its little contribution to the calculation of AOD. The two regenerated aerosol species are not available because of the experimental design, which configures RAMS to disable microphysics parameterization (see section 4). The optical properties of the six aerosol species at $550 \mathrm{~nm}$ under dry conditions are provided in Table 1. The mass 20 extinction coefficient is computed using the Mie theory (Bohren and Huffman, 1983), in which the spherical assumption of aerosol particles is required. For each of the aerosol species, particles are first grown hygroscopically to equilibrium with ambient relative humidity using $\kappa$-Köhler theory (Petters and Kreidenweis, 2007) and the refractive index is adjusted based on volume mixing with water. To reduce computational expense, a lookup table of the mass extinction coefficient as a function of ambient relative humidity (RH, \%) for each of the six aerosol species at $550 \mathrm{~nm}$ is prepared (similar to Kliewer et 25 al., 2018 and Zupanski et al., 2018). A 1\% interval of RH is used in the lookup table, which is plotted in Fig. 2. For a simulated RH with a value that falls between two integer numbers (e.g., $85.6 \%$ ), the integer value that is closer to the simulated value will be used (e.g., $86 \%$ ).

\section{Case Study}

Situated in one of the major dust sources of the world, the so-called dust belt, the Arabian Peninsula, in general, regularly 30 experiences dust storms. In particular, dust storms are found to be more frequent in the summer time of the southern Arabian 
Atmos. Chem. Phys. Discuss., https://doi.org/10.5194/acp-2018-1249

Manuscript under review for journal Atmos. Chem. Phys.

Discussion started: 17 December 2018

(c) Author(s) 2018. CC BY 4.0 License.

(c) (i)

Atmospheric

Chemistry

and Physics

Discussions

Peninsula (Jish Prakash et al., 2015). On 4 August 2016, two distinct dust plumes occurred, in which one plume advected offshore of the United Arab Emirates (UAE) to central portion of the Persian Gulf (referred to as the Persian Plume) and the other plume was located in interior portion of Saudi Arabia (referred to as the Saudi Plume). The Saudi Plume was well detected by MeteoSat Second Generation (MSG) imagery with a dust enhancement (Miller et al., 2017) applied, revealing

5 the dust in yellow (Fig. 3a). At times, dust plumes, in general, are evident in satellite imagery of so-called reflective bands. A true colour image was generated from MODIS aboard Aqua that exhibits the Persian Plume (Fig. 3b). Note, each image is unable to reveal both dust plumes; that is, the dust enhancement only captures the Saudi Plume (bright yellow) and not the Persian Plume (no yellow), while the true colour image captures only the Persian Plume but not the Saudi Plume. The existence of the Persian Plume in the true colour image (Fig. 3b) provides support that the IR-based dust detection algorithm

10 missed the Persian Plume (Fig. 3a).

As pointed out by Jish Prakash et al., (2015), the Arabian Peninsula is an under-sampled region of observations. As a result, reanalysis data from the Global Forecast System (GFS) will be used to provide some meteorological fields on 1200 UTC 4 August 2016 (Fig. 4). As indicated in Fig. 4, the environment of the Saudi Plume is characterized by northerly flow and

15 relatively low total precipitable water (TPW) $(\sim 25 \mathrm{~mm})$. In contrast, the Persian Plume is in an environment characterized by southeasterly winds and TPW values in excessive of $45 \mathrm{~mm}$. Additional details regarding the case study can be found in Miller et al., (2018).

\section{Experimental Design}

20

In this study, the RAMS-MLEF system is used to study the above-mentioned two-dust-plume event over the Arabian Peninsula on 4 August 2016. As was mentioned, RAMS serves as the forecast component of the RAMS-MLEF. Configuration of RAMS used for this case study is now described. Only one grid is used and has $15 \mathrm{~km}$ horizontal grid spacing in both horizontal directions (see Fig. 5). In addition, forward integration uses the leapfrog time-differencing scheme

25 that employs a fixed time step of 30 seconds. There are $432 \times 422$ horizontal grid points that covers a geophysical area of approximately $6480 \mathrm{~km} \times 6330 \mathrm{~km}$ and a total of 50 vertical levels from surface to the model top at $22 \mathrm{~km}$ above the lowest topographical height in the domain, which in this case is sea level. Vertical grid spacing is $75 \mathrm{~m}$ at the lowest level and is stretched with a rate of 1.08 until a vertical grid spacing of $750 \mathrm{~m}$ is reached, after which the vertical grid spacing is kept at $750 \mathrm{~m}$ to the model top. Initial and boundary conditions are provided by the Global Data Assimilation System (GDAS) 1-

30 degree Final Analysis (FNL). The Naval Research Laboratory (NRL) 1-km dust source database (Walker et al., 2009) is used for dust lofting. Additional RAMS details can be found in Saleeby et al., (2018).

There are many prognostic variables in RAMS, a few of which are discussed here. Due to the complexity of potential temperature $(\theta)$ at cloud boundaries (Tripoli and Cotton, 1981), ice-liquid water potential temperature $\left(\theta_{i l}\right)$ is used in place of 
Atmos. Chem. Phys. Discuss., https://doi.org/10.5194/acp-2018-1249

Manuscript under review for journal Atmos. Chem. Phys.

Discussion started: 17 December 2018

(c) Author(s) 2018. CC BY 4.0 License.

$\theta$. In addition, $\theta_{i l}$ is dependent on the mass mixing ratio of microphysical species. One may consider any one of the observed microphysical species, such as cloud droplets, and particles within observed "blowing dust", such as clay particles, as suspended aerosol within the atmosphere of the Earth. As a first step, RAMS will be run dry; that is, simulated microphysical species will remain inactive. As a result, water vapour is the only prognostic microphysical conservative water

5 type in the experiments, to discussed below; another consequence is that $\theta_{i l}$ is equivalent to $\theta$. In addition, the interpretation of the assimilation of observed AOD will be simplified by the absence of simulated microphysical species. Since AOD is dependent on RH, a simplified interpretation of assimilation is facilitated by the removal of microphysical species that compete for water vapour. In other words, water vapour is the only water species that will interact with the six aerosol species from which AOD is computed at $550 \mathrm{~nm}$.

10

For the case study herein, blowing dust occurred in a somewhat cloud free area as discussed in Section 3; therefore, there exists some observational support for running the forecast model dry. As described in Section 2.3, RH is used in the calculation of AOD. Since RAMS is run dry, diagnosed values of RH at areas where upward motions occur (i.e., sloping terrain) can exceed $100 \%$ because no condensate was allowed to form and water vapour was conserved. As a consequence

15 of RH $>100 \%$, simulated values of AOD reached approximately one order of magnitude larger than observed values near sloping terrain in the experiments. Relatively larger difference between simulated and observed values of AOD creates biases that are large enough to cause rejection of AOD observations that could have been assimilated. To alleviate the introduction of large biases due to running the model dry, during the computation of AOD, only grid points that have RH values less than $100 \%$ are included in the vertical summation of (3).

Configuration of MLEF used for this study is described here. A time-lagged methodology (Zupanski et al., 2006) is used to generate an initial set of ensemble forecasts of size 32 from RAMS, which are valid at 0000 UTC 3 August 2016. During the cost function minimization, a generalized quasi-Newton algorithm is used (Zupanski et al., 2008). A list of control variables include the three-dimensional wind components $(u, \mathrm{v}$, and $w)$, perturbation Exner function (pi), ice-liquid water potential temperature $\left(\theta_{i l}\right)$, total water (water vapour and all condensate types) mass mixing ratio ( $r t p$ ), and the two mineral dusts (dust1 and dust2). As a consequence of a leapfrog scheme, there exists two temporal solutions for some RAMS prognostic variables. In addition, there is a procedure in RAMS that is designed to prevent the two temporal solutions from diverging. Due to the use of leapfrog scheme in RAMS, MLEF will alter prognostic variables on one of the temporal solutions. In order to prevent both temporal solutions from diverging, a methodology is used in MLEF that keeps the difference between the two time solutions "close".

Two parallel RAMS-MLEF experiments are carried out from 0000 UTC 3 August to 0600 UTC 4 August 2016 with 6 hourly data assimilation cycle (total of 6 cycles). The ATMONLY experiment assimilates conventional atmospheric observations from NCEP PrepBUFR dataset, while the ATMAOD experiment assimilates both the atmospheric observations 
Atmos. Chem. Phys. Discuss., https://doi.org/10.5194/acp-2018-1249

Manuscript under review for journal Atmos. Chem. Phys.

Discussion started: 17 December 2018

(c) Author(s) 2018. CC BY 4.0 License.

(c) (i)

from NCEP PrepBUFR and $550 \mathrm{~nm}$ MODIS AOD retrievals. In Fig. 5, the NCEP PrepBUFR dataset used in both experiments is displayed over the RAMS domain described earlier. Note that the majority of the dataset is only available at surface (green, blue, and orange symbols), while rawinsonde (red symbol) is the single source of data that provides vertical aspect of the atmosphere. Due to the availability of MODIS AOD retrievals, they are assimilated at the $2^{\text {nd }}, 3^{\text {rd }}$, and $6^{\text {th }}$ cycle

5 (0600 UTC and 1200 UTC 3 August and 0600 UTC 4 August) for the ATMAOD experiment. For the study herein, observation error for the AOD retrievals is 0.1 (unit less). Similar to Liu et al., (2011), observation error is increased by 5\% $(15 \%)$ of the AOD value when it is over land (ocean). In order to reduce the effects of spatial observation error correlation, data thinning is applied to the AOD retrievals prior to the actual assimilation. For a given cycle, AOD retrievals are thinned in a way that only every third of pixels of a given retrieval image is retained. Once spatial thinning is completed, the next

10 step is quality control. During the quality control, the so-called gross check is applied to remove large differences (three times the prescribed observation errors) between the AOD retrievals and first-guess.

\section{Results}

\subsection{Observed vs. Model Equivalent AOD Before and After Data Assimilation}

As one of the means to evaluate the success of a data assimilation experiment, it is a common practice to examine the model

15 equivalent observation quantity before and after the assimilation. In Fig. 6, the assimilated MODIS AOD retrievals (thinned and passed quality control) are presented along with model equivalent AOD that are computed from the first guess of both ATMONLY and ATMAOD experiments and analysis of the ATMAOD experiment that are valid at 0600 UTC 4 August, 2016 , the $6^{\text {th }}$ cycle of both experiments. At first glance, there is obviously a lack of AOD retrievals over the Arabian Peninsula (Fig. 6a), although areas adjacent to the Arabian Peninsula such as Red Sea, Persian Gulf, and Gulf of Omaha 20 have some coverage. This is because the AOD retrievals were derived from the MODIS data as shown in Fig. 3b, in which the Persian Plume was well detected while the Saudi Plume was missing. In terms of the two plumes of interest, the first guess of ATMONLY (Fig. 6b) and ATMAOD (Fig. 6c) experiments has different representations of AOD distributions and magnitude, although both have the two plumes in place. After assimilating the AOD retrievals, the analysis of ATMAOD experiment further strengthens the areal extent and magnitude of the Persian Plume as well as AOD signals in Gulf of 25 Omaha. However, due to the lack of observations that are indicative of aerosol (AERONET data was not available during the period of the experiments for the Mezaira site and Masdar Institute site, which are the two sites that are located in the UAE), a quantitative verification for the above-mentioned adjustment is unrealistic. Instead, a different perspective to evaluate the data assimilation experiments is provided via an examination of information measure. 
Atmos. Chem. Phys. Discuss., https://doi.org/10.5194/acp-2018-1249

Manuscript under review for journal Atmos. Chem. Phys.

Discussion started: 17 December 2018

(c) Author(s) 2018. CC BY 4.0 License.

(c) (i)

\subsection{Information Measure in Data Assimilation}

As pointed out by Zupanski et al. (2007), it is useful to compare information measures obtained in different data assimilation approaches. One information measure that is often used in information theory as well as data assimilation is degrees of freedom for signal (DFS, Rodgers, 2000), which is defined by

$5 \quad D F S=\operatorname{trace}\left[\mathbf{I}_{\text {state }}-\mathbf{P}_{\mathbf{a}} \mathbf{P}_{\mathbf{f}}^{-1}\right]$

where trace is the trace operator of a square matrix, $\mathbf{I}_{\text {state }}$ is an identity matrix of dimension $N_{\text {state }} \mathrm{x} N_{\text {state }}$ ( $N_{\text {state }}$ is number of state vectors), and $\mathbf{P}_{\mathbf{a}}$ is the analysis error covariance of the same dimension as $\mathbf{I}_{\text {state }}$. As indicated by (4), DFS measures the forecast error reduction due to new information brought to the assimilation by observations. Following Zupanski et al. (2007), by introducing the information matrix in ensemble subspace $\mathbf{C}$, which is given by

\section{$\mathbf{C}=\mathbf{Z}^{T} \mathbf{Z}$}

$\mathbf{z}^{i}=\mathbf{R}^{-1 / 2} h\left(\boldsymbol{x}+\mathbf{p}_{\mathrm{f}}^{i}\right)-\mathbf{R}^{-1 / 2} h(\boldsymbol{x})$

where vector $\mathbf{z}^{\mathrm{i}}$ is the $\mathrm{i}^{\text {th }}$ column of the matrix $\mathbf{Z}$ of dimension $N_{\text {ens }} \times N_{\text {ens }}$ ( $N_{\text {ens }}$ is number of ensemble members), vector $\mathbf{p}_{\mathrm{f}}^{\mathrm{i}}$ is the $\mathrm{i}^{\text {th }}$ column of the forecast error covariance matrix $\mathbf{P}_{\mathrm{f}},(4)$ can be further reduced, in terms of eigenvalues $\lambda_{\mathrm{i}}$ of $\mathbf{C}$, to

$D F S=\sum_{i}^{N_{\text {ens }}} \frac{\lambda_{i}^{2}}{\left(1+\lambda_{i}^{2}\right)}$

Now it becomes clear that the value of DFS is non-negative and should have a range between 0 and $N_{\text {ens }}$ according to (6). A

15 value that is close to zero suggests that there is minimal reduction of uncertainty due to assimilation of observations, i.e., negligible impact from assimilating observations. On the other hand, a value near $N_{\text {ens }}$ would be optimal. Note that DFS with a value that is equal to $N_{\text {ens }}$ is almost impossible because it is very difficult to have a set of ensemble members that are linearly independent.

20 Using the formulation in (6), DFS were computed for the ATMONLY and ATMAOD experiments. In Fig. 7, DFS computed from the analysis of $6^{\text {th }}$ cycle of ATMONLY experiment and that of the ATMAOD experiment are displayed side by side. The maximum value of DFS for the ATMONLY case is 1.67 (Fig. 7a), and the maximum value of DFS for the ATMAOD case is 3.74 (Fig. 7b). Both of which is not a significant number, i.e., not close to $N_{\text {ens }}=32$. However, assimilation of AOD appears to be beneficial to the reduction of uncertainty, as opposed to only assimilating atmospheric observations. In

25 addition, the areal extent of non-zero DFS values is generally larger in the ATMAOD experiment, especially in the Red Sea, Persian Gulf, and Gulf of Omaha where MODIS AOD retrievals were available (Fig. 6a).

Additional information brought by AOD not only reduces the forecast uncertainty but also introduces substantial adjustments to the first guess, which are often referred to as analysis increment (analysis minus first guess) in the field of data 30 assimilation. 
Atmos. Chem. Phys. Discuss., https://doi.org/10.5194/acp-2018-1249

Manuscript under review for journal Atmos. Chem. Phys.

Discussion started: 17 December 2018

(c) Author(s) 2018. CC BY 4.0 License.

\subsection{Analysis Increment}

In this section, analysis increments of some of the control variables (Section 4) from the ATMONLY and ATMAOD

5 experiments are discussed. Fig. 8 illustrates the analysis increments of total dust (dust1 and dust $2, \mu \mathrm{g} \mathrm{kg}^{-1}$ ), ice-liquid water potential temperature $(\mathrm{K})$, total water mass mixing ratio $\left(\mathrm{g} \mathrm{kg}^{-1}\right)$, and horizontal wind components $\left(\mathrm{m} \mathrm{s}^{-1}\right)$ from the two experiments at model level 11, which is approximately $1 \mathrm{~km}$ above aground. A side-by-side comparison between the analysis increments from the two experiments reveals that there are considerable adjustments from assimilating AOD retrievals. Analysis increments from the ATMONLY experiment, in general, have smaller spatial extent and are negligible in

10 size, which are likely a consequence of the paucity of conventional atmospheric observations in this region. In contrast, analysis increments from the ATMAOD experiment are evident along Persian Gulf, Iraq, western and northern Iran, Red Sea, east Sudan, Gulf of Aden, and northern Arabian Sea. However, due to the lack of AOD retrievals, no increments were found interior of the Arabian Peninsula. While it is often challenging to identify any sort of relationship between the analysis increments of one variable and that of the other variable, it is clear that positive increments of total dust appear to match the

15 locations of positive increments of horizontal wind speed (Figs. 8 a, b, g, and h). Such finding suggests that there exists a positive correlation between dust variables and horizontal winds in the forecast error covariance.

\subsection{Impact on Forecast}

Both analyses of the ATMONLY experiment and the ATMAOD experiments valid at 0600 UTC 4 August 2016 are used to initialize a 12-h forecast. Due to the lack of observations over the Arabian Peninsula, the aerosol reanalysis product 20 contained in the Modern-Era Retrospective Analysis for Research and Applications, version 2 (MERRA-2, Gelaro et al., 2017, Randles et al., 2017) dataset is used in place of the true state of aerosol. As a reanalysis product, MERRA-2 includes assimilation of AOD retrievals from various instruments aboard satellites such as MODIS, the Advanced Very High resolution Radiometer (AVHRR), and the Multiangle Imaging SpectroRadiometer (MISR) as well as direct measurements of AOD from ground-based AERONET. In addition, MODIS AOD retrievals that were not included for assimilation in the two experiments are also used along with the MERRA-2 aerosol reanalysis product.

In Fig. 9, the AOD field from the MERRA-2 product (Fig. 9a) and the MODIS AOD retrievals valid at 1200 UTC 4 August 2016 (Fig. 9b) are displayed alongside the model equivalent AOD computed from the 6-h forecasts of the ATMONLY (Fig. 9c) and ATMAOD experiments (Fig. 9d). Similar to the findings in Fig. 6, both the Persian Plume and the Saudi Plume are 30 captured by the ATMONLY forecast and the ATMAOD forecast. However, the two forecasts overall underestimate the areal extent of the Saudi Plume, although the magnitude and areal extent of Persian plume is better represented by the ATMAOD forecast. Similar trend is also found in the 12-h forecast (Fig. 10), in which the ATMAOD forecast continues to have a more 
Atmos. Chem. Phys. Discuss., https://doi.org/10.5194/acp-2018-1249

Manuscript under review for journal Atmos. Chem. Phys.

Discussion started: 17 December 2018

(c) Author(s) 2018. CC BY 4.0 License.

(c) (i)

Atmospheric

Chemistry

and Physics

Discussions

accurate representation of the Persian Plume while the Saudi Plume is poorly captured by both ATMAOD and ATMONLY forecasts.

\section{Summary and Conclusions}

5 The goal of this research is to improve aerosol weather forecast by assimilating atmospheric and aerosol observations, hence, an atmosphere-aerosol coupled data assimilation system, RAMS-MLEF, is developed and tested. RAMS-MLEF uses the forward component of GSI as the observation operator for atmospheric observations. However, the AOD observation operator embedded in GSI is specifically designed for GOCART aerosol species. An AOD observation operator for RAMS aerosol species is required and has been built for the study herein. To demonstrate the capability of the RAMS-MLEF

10 system, a dust event over the Arabian Peninsula on 4 August 2016 is selected to conduct two experiments. This dust event includes two dust plumes, in which one plume advected offshore of the UAE to the Persian Gulf (Persian Plume) and the other plume was located interior of Saudi Arabia (Saudi Plume). Due to the lack of in-situ observations, satellite observations indicative of aerosol, which include those derived from MODIS and MSG, are used to identify the location and timing of the two plumes. However, none of them have been able to detect both plumes together. The two experiments are

15 ATMONLY and ATMAOD, in which the ATMONLY experiment only assimilates atmospheric observations from the NCEP PrepBUFR dataset and the ATMAOD experiment assimilates both atmospheric observations and AOD retrievals from MODIS.

Results from the two experiments are discussed. First of all, a sanity check is performed to examine the model equivalent

20 AOD field before and after data assimilation along with the assimilated AOD. As expected, model equivalent AOD field computed from the analysis has an improved representation of the Persian Plume. However, due to the lack of observation indicative of aerosols interior of the Arabian Peninsula, there is no direct evaluation for that of the Saudi Plume. Using information theory, degrees of freedom for signals (DFS) are computed for both experiments and results show that the additional assimilation of AOD improves the reduction of uncertainty in the forecast error covariance. However, zero values

25 of DFS are found in the interior of the Arabian Peninsula, where the Saudi Plume was located. By examining the analysis increments of several control variables that include total dust, total water mass mixing ratio, ice-liquid water potential temperatures, and horizontal wind components between the two experiments, larger adjustments in terms of magnitude and spatial extents are found in the ATMAOD experiment, while adjustments are rather small and localized in the ATMONLY experiment. In addition, no analysis increments are evident interior of the Arabian Peninsula, which is consistent with the

30 findings from the DFS. Finally, a 12-h forecast is initialized from both ATMONLY and ATMAOD analyses that are valid at 0600 UTC 4 August 2016. The aerosol reanalysis product from the MERRA-2 dataset is used to verify the forecast due to the absence of observations indicative of aerosols in the area of interest. Results show that in both 6-h and 12-h snapshots of 
Atmos. Chem. Phys. Discuss., https://doi.org/10.5194/acp-2018-1249

Manuscript under review for journal Atmos. Chem. Phys.

Discussion started: 17 December 2018

(c) Author(s) 2018. CC BY 4.0 License.

(c) (i)

AOD forecast field, ATMAOD experiment generally has a more accurate representation of the Persian Plume, while ATMONLY and ATMAOD experiments perform relatively poor for the Saudi Plume.

This study demonstrates the capability of RAMS-MLEF as an atmosphere-aerosol coupled data assimilation system using a

5 single case study over the Arabian Peninsula. This area is known to be severely under-sampled. Specifically, conventional observations are sparse and are restricted to ground stations, and satellite observations from polar-orbiting platforms are limited due to their infrequent revisits to any specific location. One important lesson learned from this study is that the location and timing of observations largely determines the improvements achieved by data assimilation. The lack of observations also makes it very challenging to perform a quantitative verification of results obtained from data assimilation.

10 This issue may be addressed in future work by including the assimilation of AOD retrievals over deserts and turbid coastal water from geostationary satellites (Xu et al., 2017), as they can further constrain dust source functions as well as improve dust transport.

\section{Author Contributions}

15 TW and MZ contributed to the interfacing work in MLEF. SS is the RAMS developer and contributed to setup RAMS for the interface work. AK and MZ developed the AOD operator for WRF-Chem and TW modified it for RAMS with help from AK and MZ. LG contributed to the description of the case study and determining the configuration of RAMS for the assimilation experiments. QB and SA contributed in providing the look-up table of mass extinction coefficients for RAMS aerosol species. YW and JW provided MODIS AOD retrievals for the assimilation experiments. TW and MZ conducted all of the experiments. The majority of the manuscript was written by TW with consultation from all other authors.

\section{Acknowledgments}

This work is supported by the Office of Naval Research (ONR) Multidisplinary University Research Initiative (MURI) program grant N00014-16-1-2040.

\section{References}

Bohren, C. F. and Huffman, D. R.: Absoption and Scattering of Light by Small Particles, Wiley., 1983.

Chin, M., Rood, R. B., Lin, S. J., Müller, J. F. and Thompson, A. M.: Atmospheric sulfur cycle simulated in the global model GOCART: Model description and global properties, J. Geophys. Res. Atmos., 105(D20), 24671-24687, doi:10.1029/2000JD900384, 2000.

30 Collins, W. D., Rasch, P. J., Eaton, B. E., Khattatov, B. V., Lamarque, J. F. and Zender, C. S.: Simulating aerosols using a 
Atmos. Chem. Phys. Discuss., https://doi.org/10.5194/acp-2018-1249

Manuscript under review for journal Atmos. Chem. Phys.

Discussion started: 17 December 2018

(c) Author(s) 2018. CC BY 4.0 License.

chemical transport model with assimilation of satellite aerosol retrievals: Methodology for INDOEX, J. Geophys. Res. Atmos., 106(D7), 7313-7336, doi:10.1029/2000JD900507, 2001.

Cotton, W. R., Pielke Sr., R. A., Walko, R. L., Liston, G. E., Tremback, C. J., Jiang, H., McAnelly, R. L., Harrington, J. Y., Nicholls, M. E., Carrio, G. G. and McFadden, J. P.: RAMS 2001: Current status and future directions, Meteorol. Atmos.

5 Phys., 82(1-4), 5-29, doi:10.1007/s00703-001-0584-9, 2003.

Federico, S., Petracca, M., Panegrossi, G. and Dietrich, S.: Improvement of RAMS precipitation forecast at the short-range through lightning data assimilation, Nat. Hazards Earth Syst. Sci., 17(1), 61-76, doi:10.5194/nhess-17-61-2017, 2017.

Gelaro, R., McCarty, W., Suárez, M. J., Todling, R., Molod, A., Takacs, L., Randles, C. A., Darmenov, A., Bosilovich, M. G., Reichle, R., Wargan, K., Coy, L., Cullather, R., Draper, C., Akella, S., Buchard, V., Conaty, A., da Silva, A. M., Gu, W.,

10 Kim, G. K., Koster, R., Lucchesi, R., Merkova, D., Nielsen, J. E., Partyka, G., Pawson, S., Putman, W., Rienecker, M., Schubert, S. D., Sienkiewicz, M. and Zhao, B.: The modern-era retrospective analysis for research and applications, version 2 (MERRA-2), J. Clim., 30(14), 5419-5454, doi:10.1175/JCLI-D-16-0758.1, 2017.

Gómez, I., Ronda, R. J., Caselles, V. and Estrela, M. J.: Implementation of non-local boundary layer schemes in the Regional Atmospheric Modeling System and its impact on simulated mesoscale circulations, Atmos. Res., 180, 24-41,

15 doi:10.1016/j.atmosres.2016.04.020, 2016.

Grell, G. A., Peckham, S. E., Schmitz, R., McKeen, S. A., Frost, G., Skamarock, W. C. and Eder, B.: Fully coupled "online" chemistry within the WRF model, Atmos. Environ., 39(37), 6957-6975, doi:10.1016/j.atmosenv.2005.04.027, 2005.

Han, Y., van Delst, P., Liu, Q., Weng, F., Yan, B., Treadon, R. and Derber, J.: JCSDA Community Radiative Transfer Model (CRTM) - version 1., 2006.

20 Hsu, N. C., Tsay, S. C., King, M. D. and Herman, J. R.: Deep Blue retrievals of Asian aerosol properties during ACE-Asia, IEEE Trans. Geosci. Remote Sens., 44(11), 3180-3195, doi:10.1109/TGRS.2006.879540, 2006.

Jish Prakash, P., Stenchikov, G., Kalenderski, S., Osipov, S. and Bangalath, H.: The impact of dust storms on the Arabian Peninsula and the Red Sea, Atmos. Chem. Phys., 15(1), 199-222, doi:10.5194/acp-15-199-2015, 2015.

Kleist, D. T., Parrish, D. F., Derber, J. C., Treadon, R., Wu, W.-S. and Lord, S.: Introduction of the GSI into the NCEP

25 Global Data Assimilation System, Weather Forecast., 24(6), 1691-1705, doi:10.1175/2009WAF2222201.1, 2009.

Kliewer, A., Zupanski, M., Bian, Q., Atwood, S., Wang, Y. and Wang, J.: Bias Correction in Assimilation of AOD Observations with WRF-Chem, Atmos. Chem. Phys., (Sumitted), 2018.

Lee, E., Županski, M., Županski, D. and Park, S. K.: Impact of the OMI aerosol optical depth on analysis increments through coupled meteorology-aerosol data assimilation for an Asian dust storm, Remote Sens. Environ., 193, 38-53, 30 doi:10.1016/j.rse.2017.02.013, 2017.

Levy, R. C., Mattoo, S., Munchak, L. A., Remer, L. A., Sayer, A. M., Patadia, F. and Hsu, N. C.: The Collection 6 MODIS aerosol products over land and ocean, Atmos. Meas. Tech., 6(11), 2989-3034, doi:10.5194/amt-6-2989-2013, 2013.

Liu, Z., Liu, Q., Lin, H. C., Schwartz, C. S., Lee, Y. H. and Wang, T.: Three-dimensional variational assimilation of MODIS aerosol optical depth: Implementation and application to a dust storm over East Asia, J. Geophys. Res. Atmos., 116(23), 1- 
Atmos. Chem. Phys. Discuss., https://doi.org/10.5194/acp-2018-1249

Manuscript under review for journal Atmos. Chem. Phys.

Discussion started: 17 December 2018

(c) Author(s) 2018. CC BY 4.0 License.

(c) (i)

Atmospheric

Chemistry

and Physics

Discussions

19, doi:10.1029/2011JD016159, 2011.

Miller, S. D., Bankert, R. L., Solbrig, J. E., Forsythe, J. M., Noh, Y.-J. and Grasso, L. D.: A Dynamic Enhancement With Background Reduction Algorithm: Overview and Application to Satellite-Based Dust Storm Detection, J. Geophys. Res. Atmos., 122, 938-959, doi:10.1002/2017JD027365, 2017.

5 Miller, S. D., Grasso, L. D., Bian, Q., Kreidenweis, S. M., Dostalek, J., Solbrig, J. E., Bukowski, J., Van den Heever, S. C., Wang, J., Walker, A. L., Zupanski, M., Wu, T.-C. and Reid, J. S.: A Tale of Two Dust Storms: Analysis of a Complex Dust Event in the Middle East, Atmos. Chem. Phys., (To be sumbitted), 2018.

Pagowski, M., Liu, Z., Grell, G. A., Hu, M., Lin, H. C. and Schwartz, C. S.: Implementation of aerosol assimilation in Gridpoint Statistical Interpolation (v. 3.2) and WRF-Chem (v. 3.4.1), Geosci. Model Dev., 7(4), 1621-1627,

10 doi:10.5194/gmd-7-1621-2014, 2014.

Petters, M. D. and Kreidenweis, S. M.: A single parameter representation of hygroscopic growth and cloud condensation nucleus activity-Part 3: Including surfactant partitioning, Atmos. Chem. Phys., 7, 1961-1971, doi:10.5194/acp-13-10812013, 2007.

Randles, C. A., da Silva, A. M., Buchard, V., Colarco, P. R., Darmenov, A., Govindaraju, R., Smirnov, A., Holben, B.,

15 Ferrare, R., Hair, J., Shinozuka, Y. and Flynn, C. J.: The MERRA-2 aerosol reanalysis, 1980 onward. Part I: Description and Data assimilation Evaluation, J. Clim., 30(17), 6823-6850, doi:https://doi.org/10.1175/JCLI-D-16-0609.1, 2017.

Remer, L. A., Mattoo, S., Levy, R. C. and Munchak, L. A.: MODIS 3 km aerosol product: Algorithm and global perspective, Atmos. Meas. Tech., 6(7), 1829-1844, doi:10.5194/amt-6-1829-2013, 2013.

Rodgers, C. D.: Inverse methods for atmospheric sounding: Theory and practice, World Scientific Publishing, Singapore., 202000.

Rubin, J. I., Reid, J. S., Hansen, J. A., Anderson, J. L., Holben, B. N., Xian, P., Westphal, D. L. and Zhang, J.: Assimilation of AERONET and MODIS AOT observations using variational and ensemble data assimilation methods and its impact on aerosol forecasting skill, J. Geophys. Res., 122(9), 4967-4992, doi:10.1002/2016JD026067, 2017.

Saleeby, S. M. and Cotton, W. R.: A Large-Droplet Mode and Prognostic Number Concentration of Cloud Droplets in the

25 Colorado State University Regional Atmospheric Modeling System (RAMS). Part I: Module Descriptions and Supercell Test Simulations, J. Appl. Meteorol., 43(1), 182-195, doi:10.1175/1520-0450(2004)043<0182:ALMAPN>2.0.CO;2, 2004.

Saleeby, S. M. and Van den Heever, S. C.: Developments in the CSU-RAMS aerosol model: Emissions, nucleation, regeneration, deposition, and radiation, J. Appl. Meteorol. Climatol., 52(12), 2601-2622, doi:10.1175/JAMC-D-12-0312.1, 2013.

30 Saleeby, S. M., Van den Heever, S. C., Bukowski, J., Walker, A. L., Solbrig, J. E., Atwood, S., Bian, Q., Kreidenweis, S. M., Wang, Y. and Wang, J.: The Influence of Simulated Surface Dust Lofting Erodible Fraction on Radiative Forcing, Atmos. Chem. Phys., (To be submitted), 2018.

Sekiyama, T. T., Tanaka, T. Y., Shimizu, A. and Miyoshi, T.: Data assimilation of CALIPSO aerosol observations, Atmos. Chem. Phys., 10(1), 39-49, doi:10.5194/acp-10-39-2010, 2010. 
Atmos. Chem. Phys. Discuss., https://doi.org/10.5194/acp-2018-1249

Manuscript under review for journal Atmos. Chem. Phys.

Discussion started: 17 December 2018

(c) Author(s) 2018. CC BY 4.0 License.

(c) (i)

Tripoli, G. J. and Cotton, W. R.: The use of ice-liquid water potential temperature as a thermodynamic variable in deep atmospheric models, Mon. Weather Rev., (109), 1094-1102, doi:10.1175/1520-0493(1981)109<1094:TUOLLW>2.0.CO;2, 1981.

Walker, A. L., Liu, M., Miller, S. D., Richardson, K. A. and Westphal, D. L.: Development of a dust source database for

5 mesoscale forecasting in southwest Asia, J. Geophys. Res. Atmos., 114(18), doi:10.1029/2008JD011541, 2009.

Wang, H. and Niu, T.: Sensitivity studies of aerosol data assimilation and direct radiative feedbacks in modeling dust aerosols, Atmos. Environ., 64, 208-218, doi:10.1016/j.atmosenv.2012.09.066, 2013.

Wang, J., Christopher, S. A., Brechtel, F., Kim, J., Schmid, B., Redemann, J., Russell, P. B., Quinn, P. and Holben, B. N.: Geostationary satellite retrievals of aerosol optical thickness during ACE-Asia, J. Geophys. Res., 108(D23), 8657,

10 doi:10.1029/2003JD003580, 2003.

Wang, Y., Wang, J., Levy, R. C., Xu, X. and Reid, J. S.: MODIS retrieval of aerosol optical depth over turbid coastalwater, Remote Sens., 9(6), 1-12, doi:10.3390/rs9060595, 2017.

Weaver, C., da Silva, A., Chin, M., Ginoux, P., Dubovik, O., Flittner, D., Zia, A., Remer, L., Holben, B. and Gregg, W.: Direct Insertion of MODIS Radiances in a Global Aerosol Transport Model, J. Atmos. Sci., 64(3), 808-827,

15 doi:10.1175/JAS3838.1, 2007.

Wu, W.-S., Purser, R. J. and Parrish, D. F.: Three-Dimensional Variational Analysis with Spatially Inhomogeneous Covariances, Mon. Weather Rev., 130(12), 2905-2916, doi:10.1175/1520-0493(2002)130<2905:TDVAWS>2.0.CO;2, 2002.

Xu, X., Wang, J., Wang, Y., Henze, D. K., Zhang, L., Grell, G. A., McKeen, S. A. and Wielicki, B. A.: Sense size-dependent

20 dust loading and emission from space using reflected solar and infrared spectral measurements: An observation system simulation experiment, J. Geophys. Res., 122(15), 8233-8254, doi:10.1002/2017JD026677, 2017.

Zhang, J., Campbell, J. R., Hyer, E. J. E. J., Reid, J. S., Westphal, D. L. and Johnson, R. S.: Evaluating the impact of multisensor data assimilation on a global aerosol particle transport model, J. Geophys. Res. Atmos., 119(8), 4674-4689, doi:10.1002/2013JD020975.Received, 2014.

25 Zupanski, D., Hou, A. Y., Zhang, S. Q., Zupanski, M., Kummerow, C. D. and Cheung, S. H.: Applications of information theory in ensemble data assimilation, Q. J. R. ..., 133, 1533-1545, 2007.

Zupanski, M.: Maximum Likelihood Ensemble Filter: Theoretical Aspects, Mon. Weather Rev., 133(6), 1710-1726, doi:10.1175/MWR2946.1, 2005.

Zupanski, M., Zupanski, D., Vukicevic, T., Eis, K. and Vonder Haar, T.: CIRA/CSU four-dimensional variational data 30 assimilation system, Mon. Weather Rev., 133(4), 829-843, doi:10.1175/MWR2891.1, 2005.

Zupanski, M., Fletcher, S. J., Navon, I. M., Uzunoglu, B., Heikes, R. P., Randall, D. A., Ringler, T. D. and Daescu, D.: Initiation of ensemble data assimilation, Tellus, Ser. A Dyn. Meteorol. Oceanogr., 58, 159-170, doi:10.1111/j.16000870.2006.00173.x, 2006.

Zupanski, M., Navon, I. M. and Zupanski, D.: The Maximum Likelihood Ensemble Filter as a non-differentiable 
Atmos. Chem. Phys. Discuss., https://doi.org/10.5194/acp-2018-1249

Manuscript under review for journal Atmos. Chem. Phys.

Discussion started: 17 December 2018

(c) Author(s) 2018. CC BY 4.0 License.

minimization algorithm, Q. J. R. Meteorol. Soc., 134, 1039-1050, 2008.

Zupanski, M., Kliewer, A., Wu, T.-C., Apodaca, K., Bian, Q., Atwood, S., Wang, J., Wang, Y. and Miller, S.: Assimilation of AOD and atmospheric observations using WRF-Chem and strongly-coupled data assimilation system, Atmos. Chem. Phys., (To be Submitted), 2018.

5 Županski, M.: Data Assimilation for Coupled Modeling Systems, in Data Assimilation for Atmospheric, Oceanic and Hydrologic Applications, vol. III, edited by S.-K. Park and L. Xu, pp. 1-553, Springer-Verlag Berlin Heidelberg., 2017.

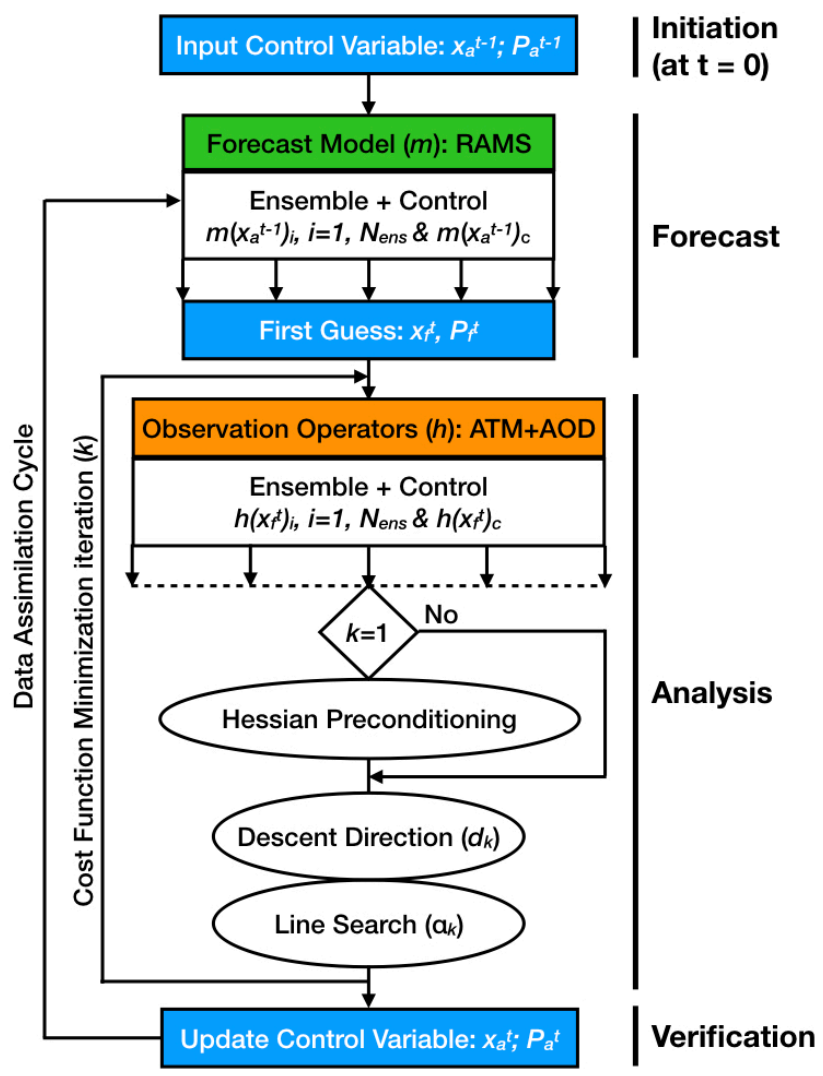

Figure 1: A flow chart of MLEF with interfaces to RAMS highlighted in colors: blue boxes represent interfaces for I/O between 10 MLEF and RAMS, green box represents the interface as a driver to call and run RAMS, and orange box represents the interface for observation operators, which requires input from RAMS. 
Atmos. Chem. Phys. Discuss., https://doi.org/10.5194/acp-2018-1249

Manuscript under review for journal Atmos. Chem. Phys.

Discussion started: 17 December 2018

(c) Author(s) 2018. CC BY 4.0 License.
Atmospheric

Chemistry

and Physics

Discussions

(c) (i)

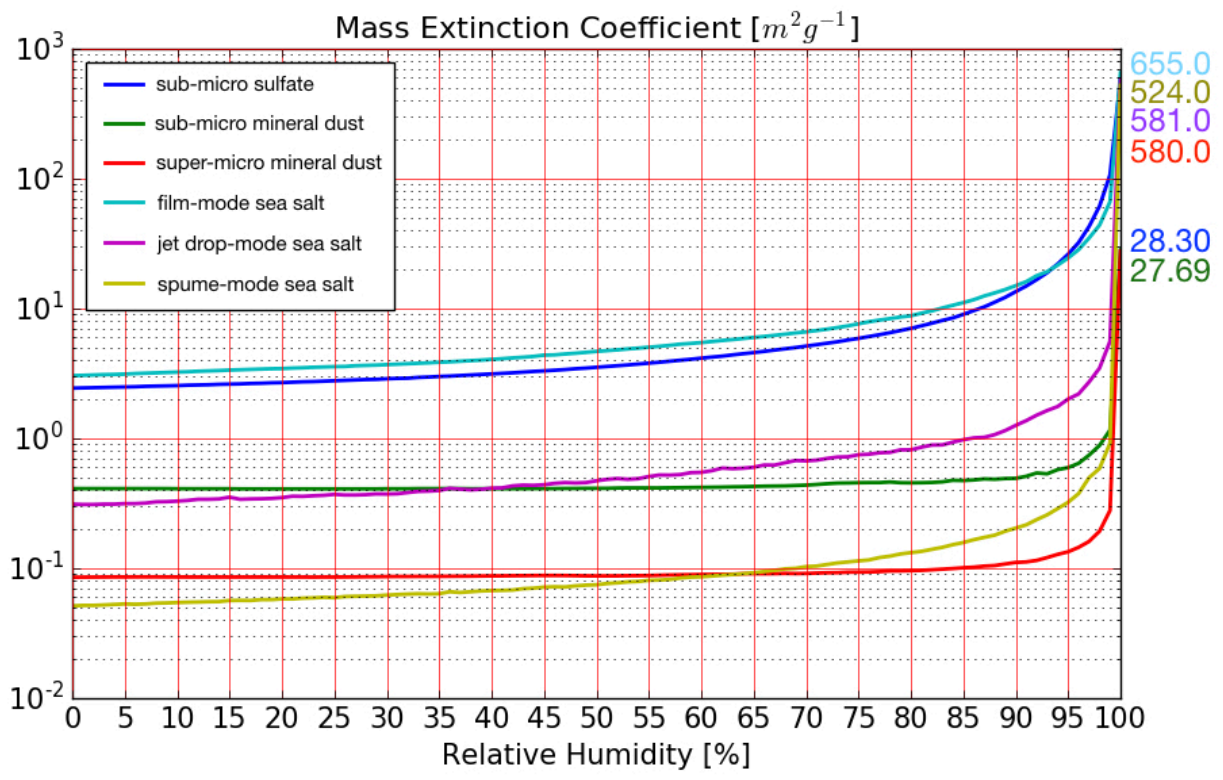

Figure 2: Mass extinction coefficient $\left(\mathrm{m}^{2} \mathrm{~g}^{-1}\right)$ as a function relative humidity $(\%)$ at $550 \mathrm{~nm}$ for the six RAMS aerosol species listed in Table 1. Colored numbers on the right hand side of the figure indicate values of mass extinction coefficient at $\mathrm{RH}=100 \%$.

(a) MSG with dust enhancement: 13 UTC 4 August 2016

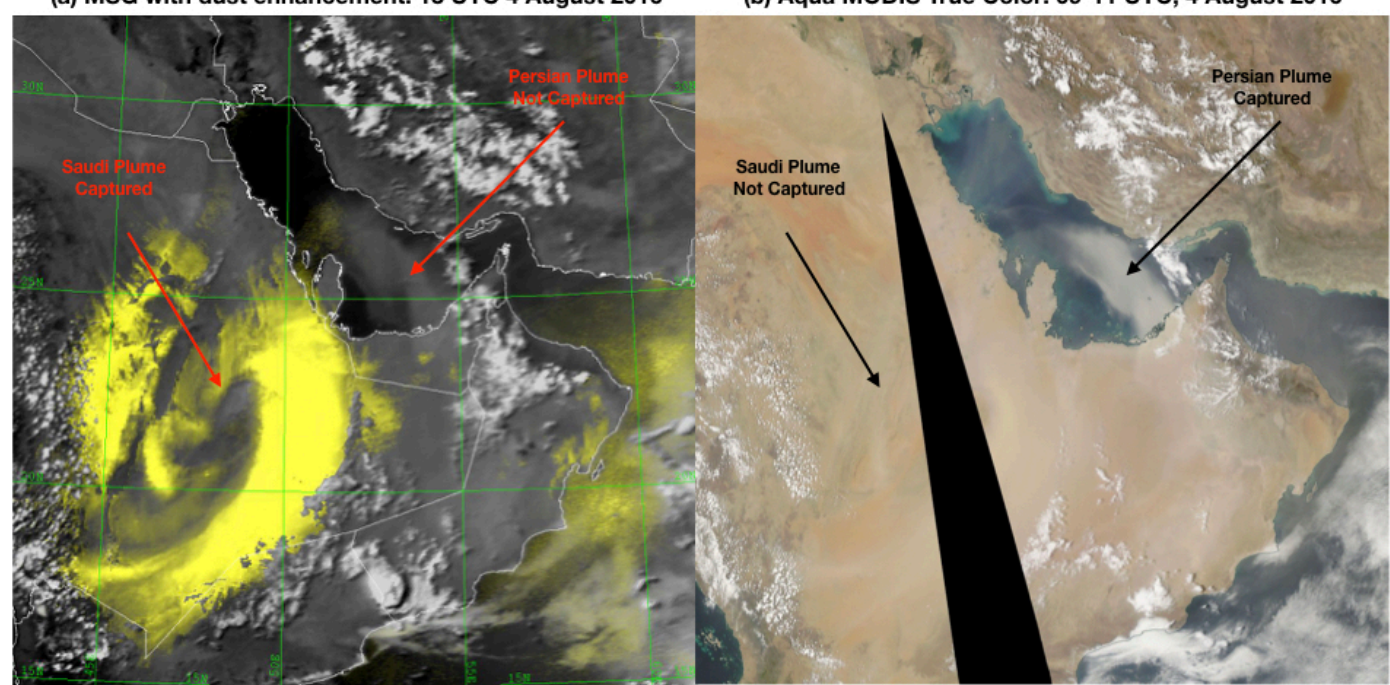

5 Figure 3: Satellite imagery of the two dust plumes over the Arabian Peninsula on 4 August 2016: (a) Meteosat Second Generation (MSG) imagery with dust enhancement applied (showing dust in yellow). (b) Aqua MODIS true colour imagery. 
Atmos. Chem. Phys. Discuss., https://doi.org/10.5194/acp-2018-1249

Manuscript under review for journal Atmos. Chem. Phys.

Discussion started: 17 December 2018

(c) Author(s) 2018. CC BY 4.0 License.

\section{Atmospheric \\ Chemistry \\ and Physics \\ Discussions}
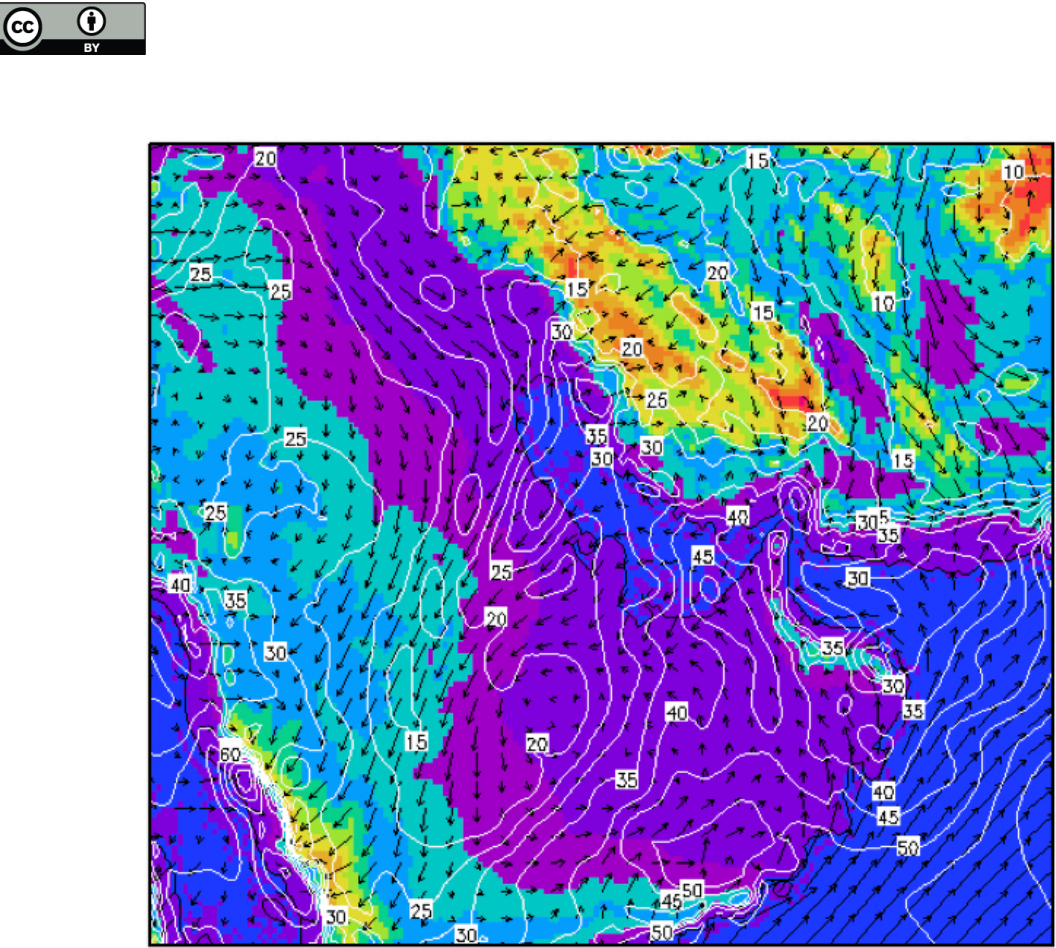

Total Precipitable Water $(\mathrm{mm})$ Wind vector scale: $\overrightarrow{20} \mathrm{~m} / \mathrm{s}$

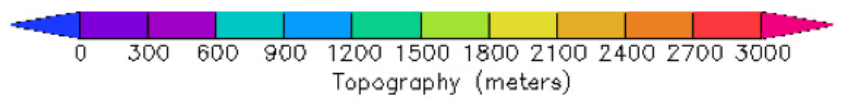

Figure 4: Meteorological fields from the Global Forecast System (GFS) reanalysis along with surface topography (m) from WRFARW. Surface wind vectors $\left(\mathrm{m} \mathrm{s}^{-1}\right)$ and total precipitable water (mm) are valid at 1200 UTC 4 August 2016 over the Arabian Peninsula. 
Atmos. Chem. Phys. Discuss., https://doi.org/10.5194/acp-2018-1249

Manuscript under review for journal Atmos. Chem. Phys.

Discussion started: 17 December 2018

(c) Author(s) 2018. CC BY 4.0 License.

(c) (i)

\section{Atmospheric \\ Chemistry \\ and Physics \\ Discussions}

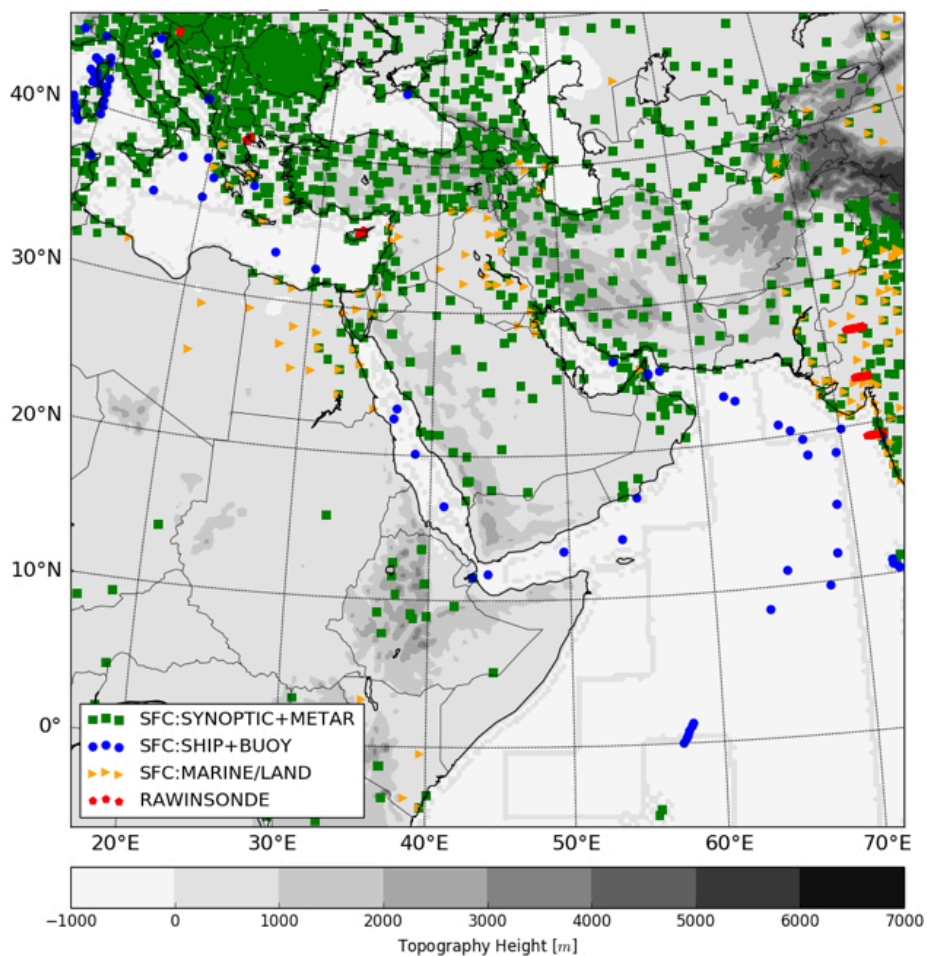

Figure 5: PrepBUFR dataset that are assimilated into the ATMONLY and ATMAOD experiments over the RAMS domain discussed in Experimental Design (Section 4). Topography height $(m)$ is plotted in grey scale. 
Atmos. Chem. Phys. Discuss., https://doi.org/10.5194/acp-2018-1249

Manuscript under review for journal Atmos. Chem. Phys.

Discussion started: 17 December 2018

(c) Author(s) 2018. CC BY 4.0 License.

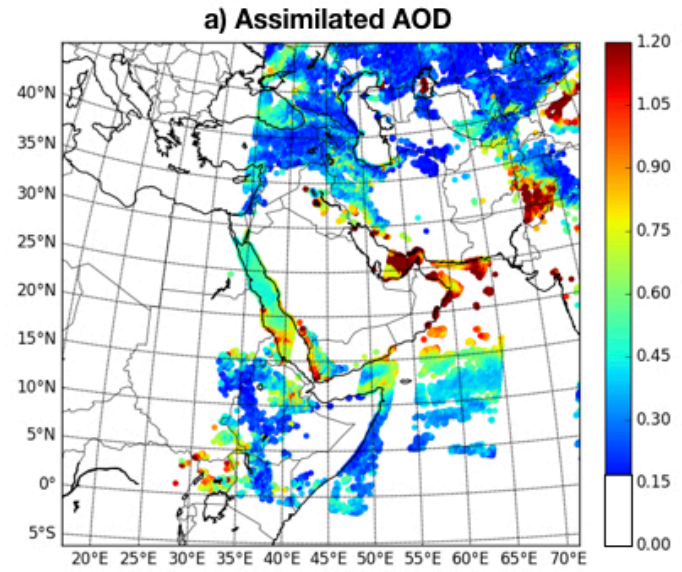

c) AOD from First Guess ATMAOD

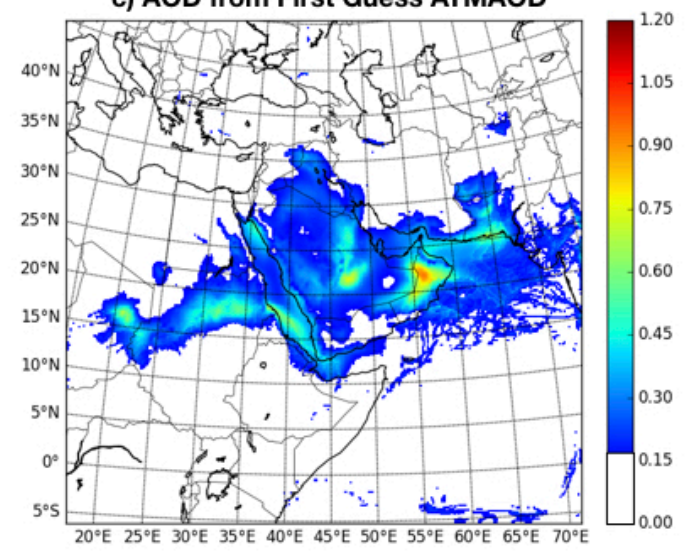

b) AOD from First Guess of ATMONLY

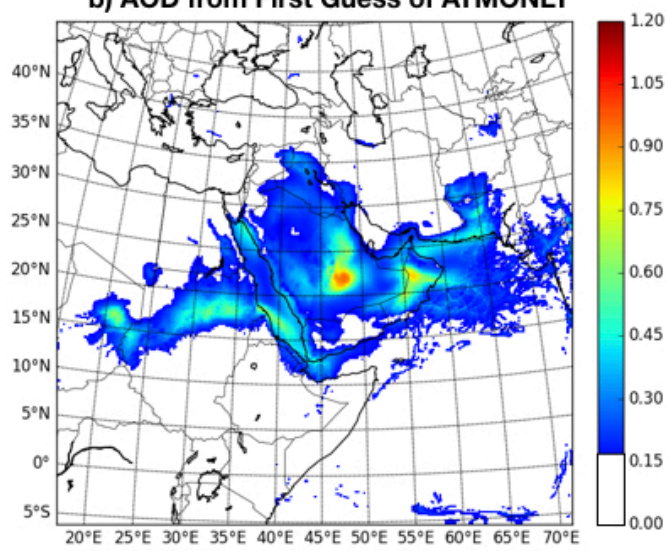

d) AOD from Analysis of ATMAOD

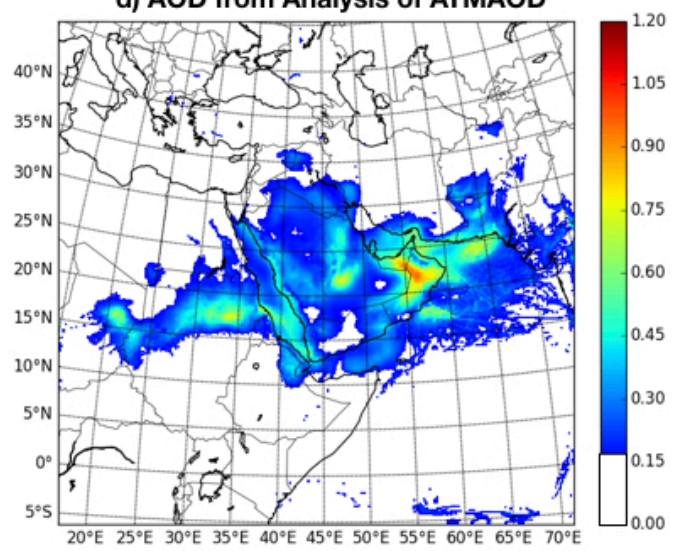

Figure 6: a) Assimilated AOD retrievals (unit less) and model equivalent AOD computed from b) the first guess of ATMONLY experiment and c) the first guess and d) analysis of ATMAOD experiment valid at 0600 UTC 4 August 2016. 
Atmos. Chem. Phys. Discuss., https://doi.org/10.5194/acp-2018-1249

Manuscript under review for journal Atmos. Chem. Phys.

Discussion started: 17 December 2018

(c) Author(s) 2018. CC BY 4.0 License.

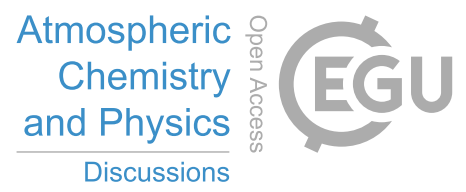

(c) (1)
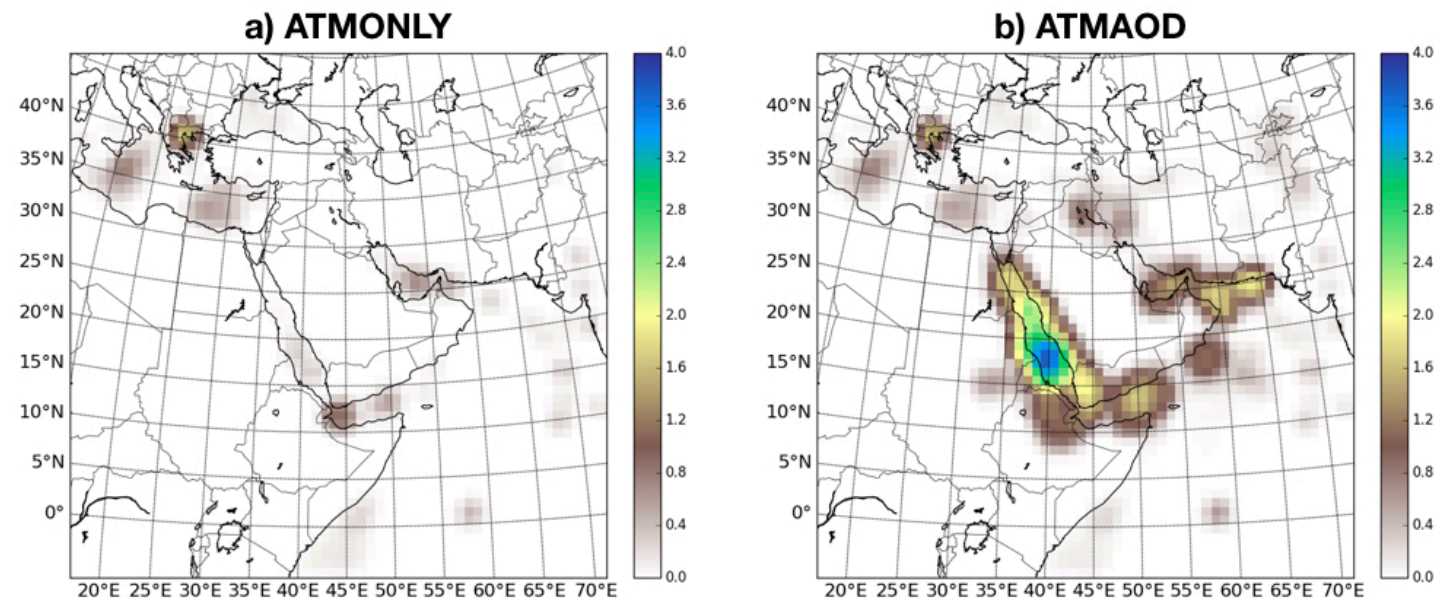

Figure 7: Degrees of Freedom for Signal (DFS) at cycle 6, valid at 0600 UTC 4 August 2016, of a) the ATMONLY and b) the ATMAOD experiment. The unit of DFS is dimension less. 
Atmos. Chem. Phys. Discuss., https://doi.org/10.5194/acp-2018-1249

Manuscript under review for journal Atmos. Chem. Phys.

Discussion started: 17 December 2018

(c) Author(s) 2018. CC BY 4.0 License.

(c) (1)
Atmospheric

Chemistry

and Physics

Discussions a) ATMONLY: total dust (ug $\mathbf{~ k g}^{-1}$ )

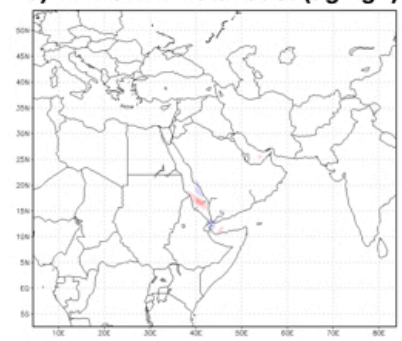

c) ATMONLY: $r t p\left(\mathrm{~g} \mathrm{~kg}^{-1}\right)$

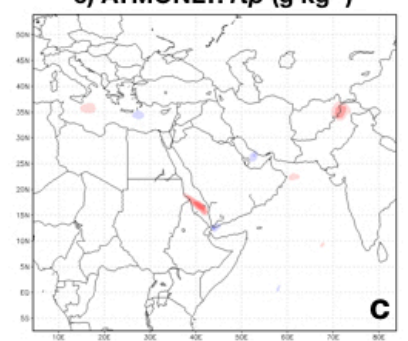

e) ATMONLY: $\theta_{i l}(\mathrm{~K})$

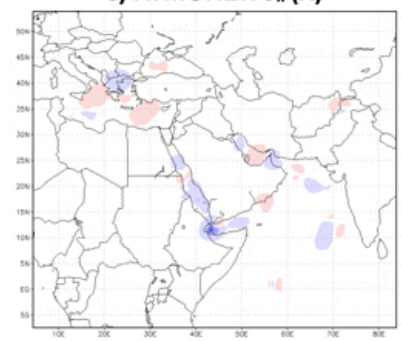

g) ATMONLY: $u, v\left(\mathrm{~m} \mathrm{~s}^{-1}\right)$

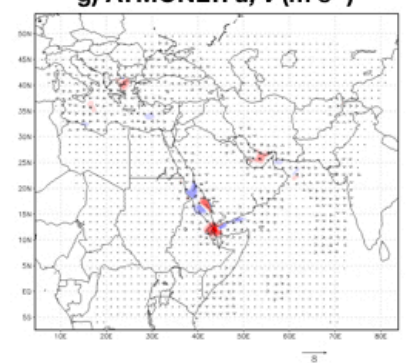

b) ATMAOD: total dust (ug $\mathbf{~ k g}^{-1}$ )

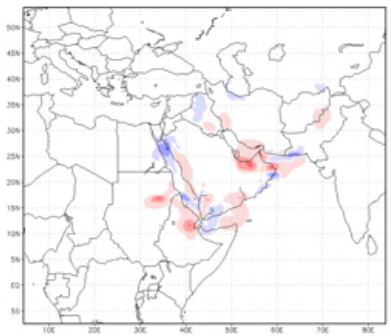

d) ATMAOD: $r$ tp ( $\left.\mathrm{g} \mathrm{kg}^{-1}\right)$

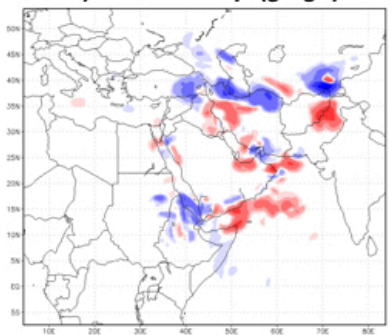

f) ATMAOD: $\theta_{i l}(\mathrm{~K})$

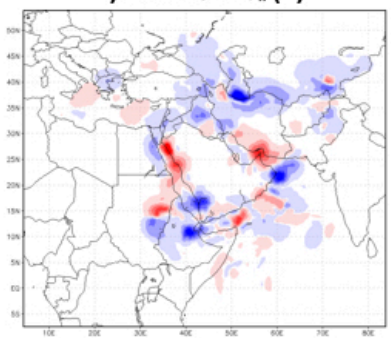

h) ATMAOD: $u, v\left(\mathrm{~m} \mathrm{~s}^{-1}\right)$

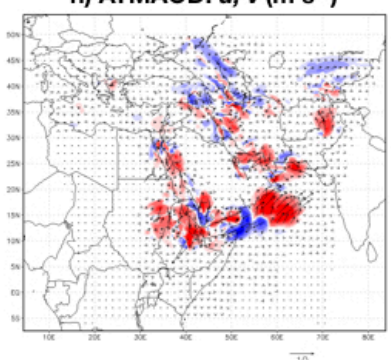

Figure 8: Analysis increment at cycle 6, valid at 0600 UTC 4 August 2016 of a) total dust (dust1+dust2, $\mu \mathrm{g} \mathrm{kg} \mathrm{g}^{-1}$ ), c) total water mass mixing ratio $\left(r t p, \mathrm{~g} \mathrm{~kg}^{-1}\right)$, e) ice-liquid water potential temperature $\left(\theta_{i l}, \mathrm{~K}\right)$, and $\mathrm{g}$ ) horizontal wind components $\left(u\right.$ and $\left.v, \mathrm{~m} \mathrm{~s}^{-1}\right)$ from the ATMONLY experiment. b), d), f), and h) are corresponding increments from the ATMAOD experiment. 
Atmos. Chem. Phys. Discuss., https://doi.org/10.5194/acp-2018-1249 Manuscript under review for journal Atmos. Chem. Phys.

Discussion started: 17 December 2018

(c) Author(s) 2018. CC BY 4.0 License.

(c) (i)
Atmospheric

Chemistry and Physics

Discussions a) MERRA-2

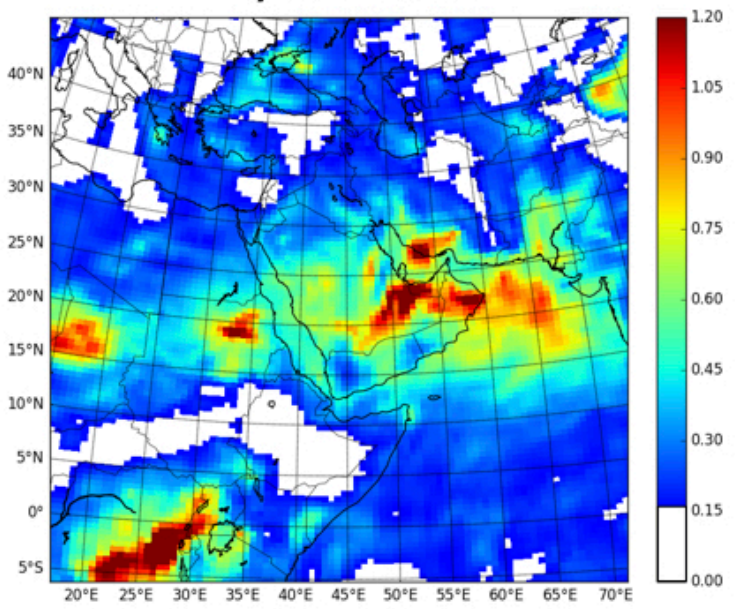

c) ATMONLY

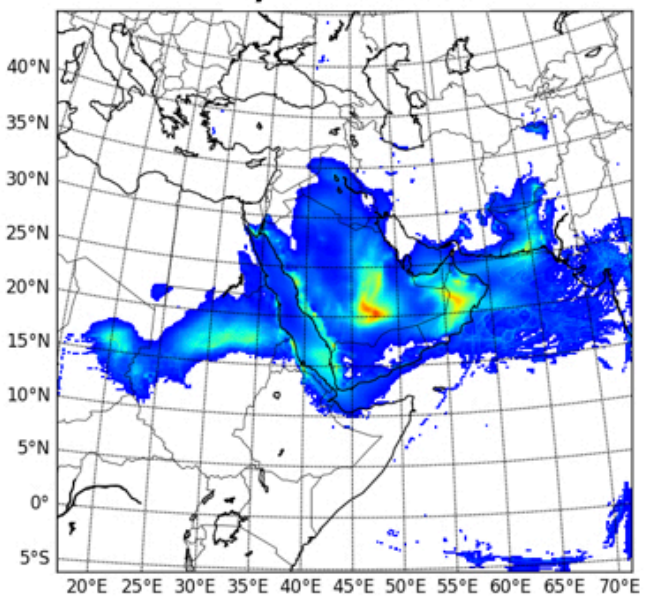

b) MODIS Retrievals

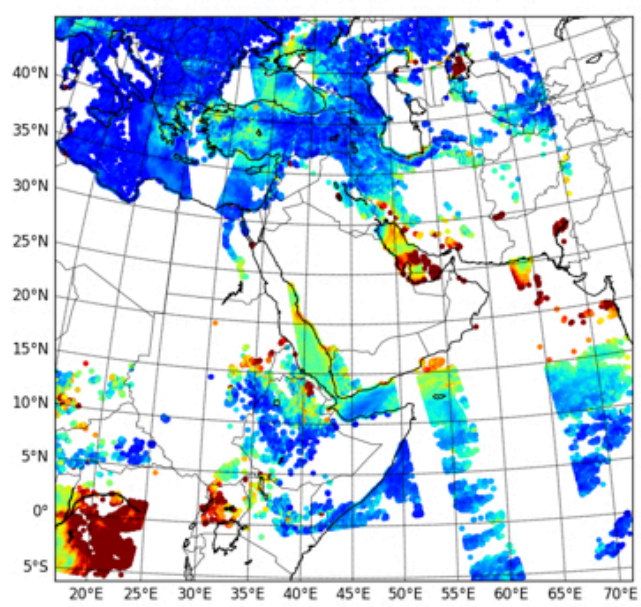

d) ATMAOD

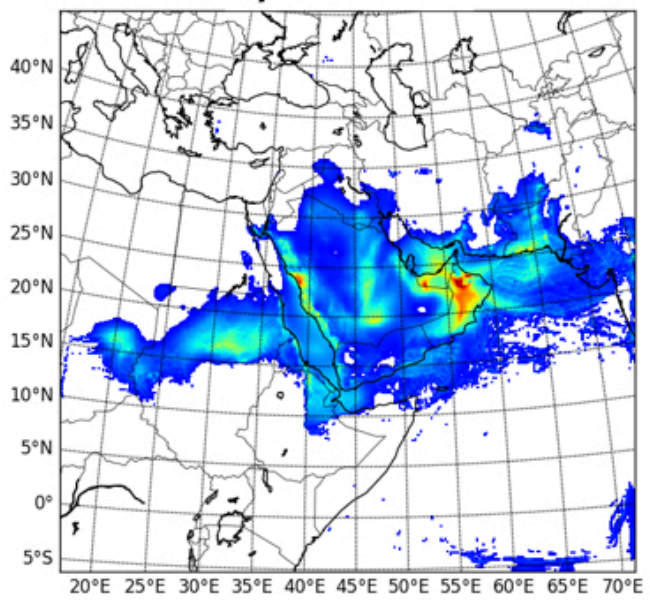

Figure 9: a) MERRA-2 AOD field and b) MODIS AOD retrievals valid at 1200 UTC 4 August 2016. Model equivalent AOD 5 computed from the 6-h forecast initialized from the c) ATMONLY and d) ATMAOD experiments. 
Atmos. Chem. Phys. Discuss., https://doi.org/10.5194/acp-2018-1249

Manuscript under review for journal Atmos. Chem. Phys.

Discussion started: 17 December 2018

(c) Author(s) 2018. CC BY 4.0 License.

(c) (1)
Atmospheric

Chemistry and Physics

Discussions a) MERRA-2

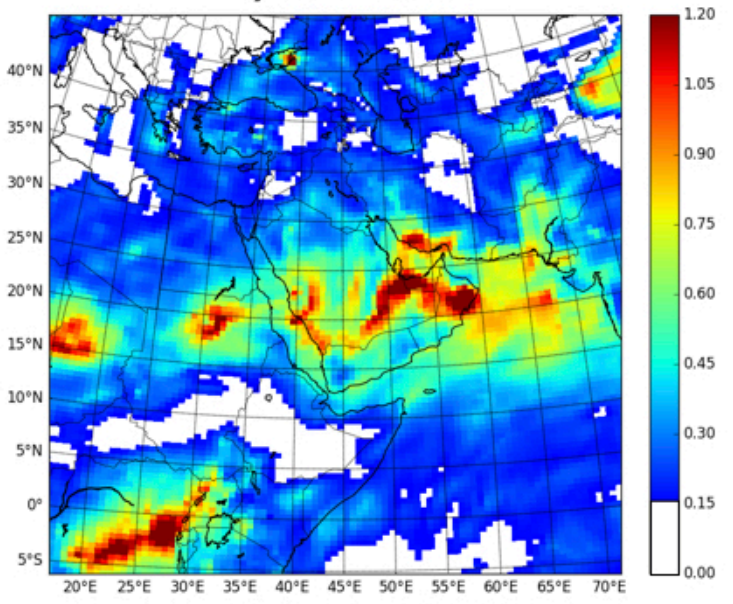

b) ATMONLY

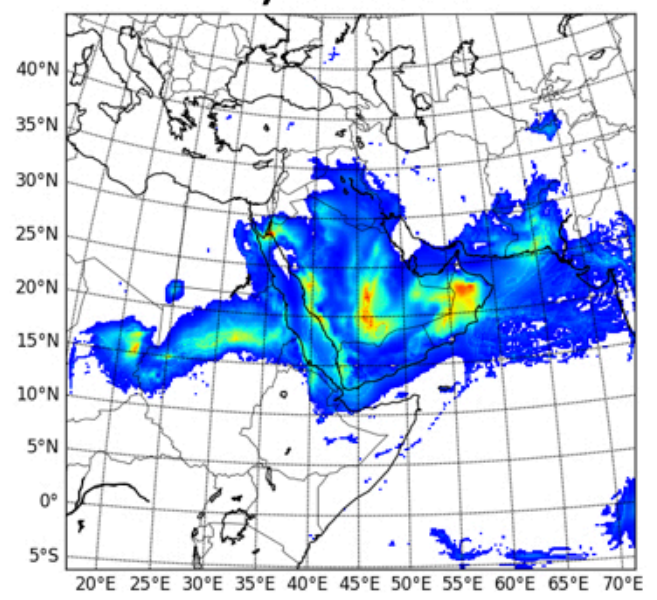

c) ATMAOD

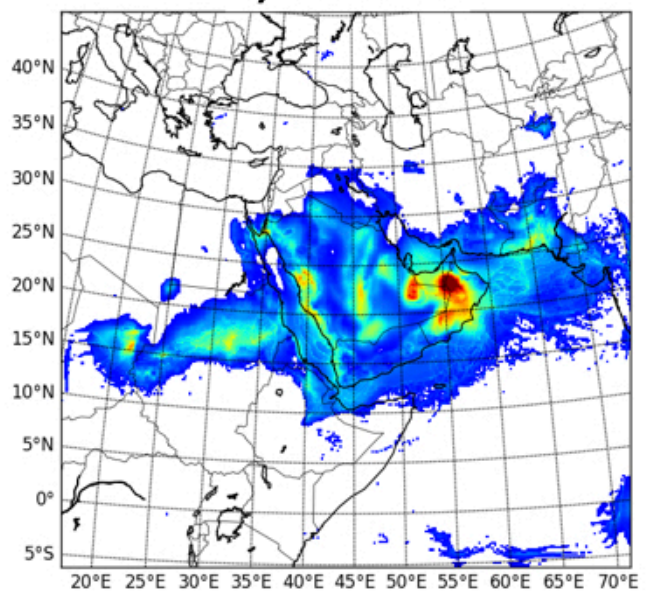

Figure 10: Similar to Figure 9, except that there is no MODIS AOD retrievals are available at 1800 UTC 4 August 2016 and the model equivalent AOD are computed from the 12-h forecast. 
Atmos. Chem. Phys. Discuss., https://doi.org/10.5194/acp-2018-1249

Manuscript under review for journal Atmos. Chem. Phys.

Discussion started: 17 December 2018

(c) Author(s) 2018. CC BY 4.0 License.

\begin{tabular}{|c|c|c|c|c|c|c|c|c|}
\hline $\begin{array}{c}\text { Aerosol } \\
\text { Species }\end{array}$ & $\begin{array}{c}\text { Geometric } \\
\text { Median } \\
\text { Diameter } \\
(\mu \mathrm{m})\end{array}$ & $\begin{array}{c}\text { Effective } \\
\text { Radius } \\
(\mu \mathrm{m})\end{array}$ & $\begin{array}{c}\text { Geometric } \\
\text { Standard } \\
\text { Deviation } \\
(\mu \mathrm{m})\end{array}$ & $\begin{array}{c}\text { Density } \\
\left(\mathrm{g} \mathrm{cm}^{-3}\right)\end{array}$ & $\begin{array}{c}\text { Index of } \\
\text { Refraction at } \\
550 \mathrm{~nm} \\
(\mathrm{real})\end{array}$ & $\begin{array}{c}\text { Index of } \\
\text { Refraction at } \\
550 \mathrm{~nm} \\
\text { (imaginary) }\end{array}$ & $\begin{array}{c}\text { Mass } \\
\text { Extinction } \\
\text { Coefficient } \\
\left(\mathrm{m}^{2} \mathrm{~g}^{-1}\right) \text { at } \\
550 \mathrm{~nm}\end{array}$ & $\begin{array}{c}\text { Hygroscop } \\
\text { icity } \\
\text { Parameter } \\
(\mathrm{kappa})\end{array}$ \\
\hline $\begin{array}{c}\text { sub- } \\
\text { micrometer } \\
\text { sulfate }\end{array}$ & 0.08 & 0.095 & 1.8 & 1.76 & 1.524 & $1.00 \mathrm{E}-07$ & 2.44 & 0.55 \\
\hline $\begin{array}{c}\text { sub- } \\
\text { micrometer } \\
\text { mineral dust }\end{array}$ & 1.398 & 1.658 & 1.8 & 2.5 & 1.5 & 0.0005 & 0.411 & 0.04 \\
\hline $\begin{array}{c}\text { super- } \\
\text { micrometer } \\
\text { mineral dust }\end{array}$ & 5.9 & 6.997 & 1.8 & 2.65 & 1.5 & 0.0005 & 0.0854 & 0.05 \\
\hline $\begin{array}{c}\text { film-mode } \\
\text { seasalt }\end{array}$ & 0.2 & 0.237 & 1.8 & 2.2 & 1.5 & $1.00 \mathrm{E}-08$ & 3.04 & 0.8 \\
\hline $\begin{array}{c}\text { jet drop-mode } \\
\text { sea salt }\end{array}$ & 2.0 & 2.372 & 1.8 & 2.2 & 1.5 & $1.00 \mathrm{E}-08$ & 0.312 & 0.8 \\
\hline $\begin{array}{c}\text { spume-mode } \\
\text { sea salt }\end{array}$ & 12.0 & 14.232 & 1.8 & 2.2 & 1.5 & $1.00 \mathrm{E}-08$ & 0.0514 & 0.8 \\
\hline
\end{tabular}

Table 1: Optical properties for the RAMS aerosol species under dry conditions and their hygroscopicity parameters. 